\title{
Practical Problems in the South-South Development Coopera- tion: Some Experiences Involving Tanzania
}

\author{
By Paschal B. Mihyo
}

\section{From Bandung to Belgrade}

The idea of South-South economic cooperation for economic chance and development was first mooted at the Afro-Asian Conference at Bandung in 1955. By then, most African and Asian countries were still colonies. All the same, a commitment was made that there was a need for economic ties between countries of the two continents. ${ }^{1}$ In 1961 , at the first meeting of the Non-Aligned Movement held in Belgrade, there were more African, Asian and Latin American countries, and further and clearer commitments were made to pursue ways of enhancing trade ties within the developing countries.

The first steps towards this kind of cooperation were taken in 1968, when Egypt, India and Yugoslavia entered into a tripartite trade agreement. In 1972, the non-aligned countries passed an action programme for economic cooperation among themselves and with other developing countries. In 1973, at the conference of the ministries of Non-Aligned Countries, the action programme was endorsed. 1976 was marked by the meeting in Mexico at which the concept of collective self-reliance was discussed to be further concretized into a programme of action at the Arusha meeting of the group of 77 in 1979. The Arusha meeting was followed by the Caracas meeting of 1981 and the Geneva conference of the Group of 77 in October 1982. These two were technical meetings which sought to work out a strategy for South-South cooperation.

Between 1982 and 1988, several serious conferences were held under the auspices of UNCTAD and the Non-Aligned Movement (NAM). In the 1983 and 1984 sessions of Group "B" country members of the UNCTAD, negotiations on the Global System of Trade Preference (GSTP) among developing countries began. With assistance from the UN, the negotiations began bearing fruit at the New Delhi conference of 1985. At the Brasilia meeting almost a year later, consensus was already emerging and following several meetings in 1986 and 1987, the GSTP among developing countries was signed at Belgrade on the 13th of April, 1988.

1 S. S. Ramphal, South-South: Parameters and Pre-Conditions, in: A. Gauhar (ed.), Third World Strategy, New York 1983, pp. 17 - 23; C. Raghavan, GSTP: A Modest Beginning for South's Collective Self-Reliance, IFDA Dossier, 67, pp. 33 - 44. 
The road from Bandung 1955 to Belgrade 1988 has been a very long and arduous one. The biggest problem has been that of unity. This can be noted from the number of signatories of the final agreement. Out of the Group of 77 countries, only 48 had ratified the agreement at the time it was officially concluded at the Belgrade Conference on 13th of April, 1988. Related to this problem, the implications of which cannot be easily ignored, although the signatories include major economic powers of the South such as Argentina, Brazil, India, Yugoslavia, Mexico and South Korea, conspicuously missing are some of the major oil producing countries such as Saudi Arabia, the United Arab Emirates, Kuwait, etc. But also missing from the list of the initial signatories are some of the poorest countries in the Group of 77, e.g. Burundi, Rwanda, Lesotho, Swaziland, Zambia, Tanzania, Nepal, Djibouti, etc. Furthermore, very few French-speaking countries seem to have participated in the initial efforts, apart from Algeria and Guinea. The 48 all seem to be, in the majority, former colonies of Britain, and those which had been taken over by the US from weaker colonial powers such as Spain and Portugal.

The second problem is that, between 1965 and 1980, a lot of cooperation initiatives were undertaken including regional integration and custom unions. Most of these in Asia, Africa and Latin America failed, and hostilities including armed conflict broke out between former partners in East Africa and West Africa and such hostilities continue between former partners in Central America. Related to this, between 1972 and 1978, the NAM identified about twenty areas of economic cooperation and tried to get about one hundred countries to utilize them to enhance trade and cooperation among themselves. Progress was not encouraging and very few took off. 2

Third was the factor of organization. Between 1976 and 1984, a lot of meetings came out with brilliant ideas and programmes of economic cooperation among developing countries (ECDC), and expert groups or high level consultation groups were formed. At the Caracas conference, for example, eighteen expert and high level groups were formed. 3 None of them produced the expected results.

The fourth problem is that of protracted negotiations. Although sub-regional groupings have been useful, negotiations for a GSTP among developing countries have taken longer than negotiations between developed countries and the whole Group of 77 through Lomé Conventions, for example. Although the reasons are obvious, the protracted negotiations are showing that, if negotiations between equals in the South are all that difficult, the North-South dialogue on the new international economic order will have to take longer.

2 Ramphal, ibd.

3 Ramphal, ibd. 
Fifth, as many observers have noted, the NAM has been much more of a forum for diplomatic action than for technical consultations, and a lot of diplomacy has gone on between the members, to such an extent that it has been difficult to create a common identity. 4 But also almost important is the fact that the image of the NAM kept on revolving around personalities such as Gandhi, Nasser, Tito and Nyerere. With their gradual exit from policies, the movement became weaker. Even regional cooperation efforts such as the tripartite agreement between India, Egypt and Yugoslavia or the East African community between Kenya, Tanzania and Uganda depended too much on the continuation of their founders in power and with the exit of one of them, they were bound to crumble and did crumble.

Other observers have noted that suspicion and petty-jealousy very much affected the initiation and continuation of effective trade ties among members of the NAM. Consensus seems to have been for quite some time very difficult to attain due to various alignments within the NAM. Very few countries have been genuinely non-aligned and open and silent conflicts usually stemmed from the alignment factor, in most cases funnelled by nonmembers of the movement. 5

In spite of these problems, however, South-South cooperation has taken off between 1965 and 1988. Although it has not managed to reserve the flow trends in both capital flows and trade, nevertheless, it is clear that between Bandung and Belgrade, foundations have been laid for a possible attainment of meaningful South-South links. Below we shall examine the forms and basic assumptions of this type of cooperation.

\section{Basic Forms and Assumptions of the South-South Cooperation}

In this section the intention is to examine the basic theoretical foundations of South-South cooperation in trade and development and the forms that this cooperation has taken so far.

\subsection{The Forms}

Direct foreign investments within developing countries have begun to form a significant feature of South-South cooperation. Wells has attributed them to attempts by investor

4 See M. Ostojic, Three Decades since Bandung, Review of International Affairs (RIA) 36 (1985), No. 843, pp. 5 - 7, and V. Mathews, The Spirit of Bandung '1955 - 1985': Thirty Years Since the Bandung Conference, Intereconomics 20 (1985), No. 5, p. 307.

5 A. I. Chicherov, Non-Alignment in Contemporary World: Some Approaches and Evaluations, RIA 37 (1986), No. 858, pp. 20 - 22, and Z. Jazic, Consensus in the Non-Aligned Movement, RIA 37 (1986), No. 859, pp. 3 - 5. 
countries to beat import restrictions in host countries, attempts to avoid anti-trust legislation in home countries, efforts to extend activities beyond limited domestic markets and to apply under-utilized technologies in less advantaged economies and a general strategy to spread risks. Other motives include getting a foothold on familiar markets in areas unexploited by local or other international capital, e.g. in the case of Brazilian companies in Africa-agricultural products.

In most cases, South-South capital flows differ from North-South ones in that they tend to have a lower level of exclusive ownership. Joint ventures with local entrepreneurs are more visible, and this could be more motivated by attempts to avoid foreign exchange controls or to comply with investment codes which require local equity participation in any form of foreign investment. Another significant feature of South-South direct foreign investments is that they are to a higher degree organized through public sector enterprises of mixed nature or exclusively owned by the home country governments. This factor makes them less suspicious and gives assurance to host governments that they may operate towards mutual advantage.

South-South direct investments have their own disadvantages. First, they involve in most cases technologies which have been acquired or copied from the North and are no longer dynamic in their countries of origin but could be temporarily useful in host countries. Such technologies cannot be relied on for the generation of technological capabilities in host countries. Secondly, as Diaz-Alejandro6 has observed, the motive of South-South direct investments is usually far from transferring of technology in terms of generation of skills and capabilities in the host country but to gain a share of the market. Third, some South companies tend to pay very low wages and their role in removing income gaps becomes negative7, and fourth, some South-South joint ventures are ethno-centric and used as forms of alliances between people of same ethnic origins operating in different countries. This is the case with Asian investments in Eastern Africa, Lebanese and Arab investments in Africa generally and Latin American investments in former Portuguese and Spanish colonies. As Carlsson 8 has pointed out, such investments lead to social tensions and may be politically disruptive.

The other forms of cooperation has been trade. It is in this area that some degree of success and a lot of problems have been recorded. Success has been in the formation of free trade areas, tariff and custom unions, barter trade and compensation or buy-back arrangements,

6 C. F. Diaz-Alejandro, Foreign Direct Investment by Latin Americans, in: T. Agmon / C. P. Kindleburger (eds.), Multinationals from Small Countries, MIT Press, Cambridge, Mass., 1977.

7 J. Carlsson (ed.), South-South Relations in a Changing World Order, Uppsala 1982.

8 J. Carlsson, ibd. 
exchange of technological know-how and technical cooperation etc. ${ }^{9}$ But it is in this area that cooperation has been erratic and inequitable. Through trade, most Southern recipients have discovered various things. First, that trade between South-South is motivated by the same pressures, especially among unequal partners - the search for cheaper raw materials in exchange for semi-finished products. This has often been the case among unequal partners in South-South transactions. The most obvious examples have been those of trade between Latin American oil producing non-industrial states, e.g. Venezuela, and more economically advanced partners such as Brazil and Argentina10, between Latin American countries such as Brazil and essential raw material producing countries in Africa, e.g. Algeria, Nigeria and South Africa11, and the advanced countries of Asia such as India and either less advantaged Asian countries or African trading partners. 12

Secondly, it has come out clearly that South-South cooperation has been characterised by the struggle for hegemony among the advanced countries of the South. These struggles have been intense in the Asian region among giants in that region mainly India, Taiwan, Korea and Pakistan13, and these struggles have greatly affected the ASEAN Preferential Trading Arrangements 1977 and the ASEAN Industrial Complementation Schemes 1981 which are the major forms of cooperation in the ASEAN region. 14

The third trend is that some partners in the South have not hesitated in using their economically advantaged position to use trade and aid as instruments for foreign policy. They have used them to increase their ideological influence over their partners. Arab countries have been leading in this regard. They have hot hesitated to use trade and aid to mobilize support or influence foreign policy or to widen their religious influence. Similarly, Cuba has not disguised its foreign and domestic policy objectives in its trade with Latin American and

9 O. Havry-Ishnyn / M. Wolf, Trade among Developing Countries: Theory, Policy Issues and Principal Trends, World Bank Working Paper, No. 479, 1981; ITC, Analysis of Actual and Potential Trade Flows Between Developing Countries, Geneva 1980; W. G. Tyler, Advanced Developing Countries as Export Competitors in the Third World Markets: The Brazilian Experience, Washington 1980.

10 See E. Lopez-Perez, Cooperation Among Developing Countries: Some Venezuelan Experience, in: Development and Peace, Vol. 1 (1980), No. 1, pp. 92 - 105, and Tyler, above, fn. 9.

11 P. H. Wartheim / C. Craig, Brazil and Africa, African Business, No. 62 (1983), pp. 59 - 63; P. D. Collins, Brazil and Africa: Perspectives on Economic Cooperation among Developing Countries, Development Policy Review, Vol. 3 (1985), No. 1, pp. 21 - 49.

12 K. Prakash-Anand et al., India and Africa, New African, No. 149 (1983), pp. 45 - 60; T. K. Jarayaman, Economic Cooperation among Afro-Asian Countries, Indian Quarterly, Vol. 33, pp. $198-215$.

13 K. L. Dalal, India's Trade and Economic Relations with Developing Countries, Economic and Commercial News, Vol. 13 (1983), No. 14, pp. 1 - 16, S. Dutt, India and the First World: Altruism or Hegemony?, London 1984.

14 U. Juoro, The economic crisis and opportunities for regional cooperation in South-east Asia, IFDA Dossier 65, pp. $33-36$. 
African partners. ${ }^{15}$ In the case of Arab countries, attempts to use trade and aid as spring boards for religious and foreign policy influence have led to tension, temporary and fluctuating coalitions and sometimes open armed and diplomatic rows. 16

Fourth, and perhaps not a permanent feature, is that, in some cases involving machinery supplies, some suppliers from the South have tended either to supply used and obsolete machinery from the North or reconditioned inferior types of machinery or, as will be shown later, they have used markets in the South as testing or dumping grounds for articles not easily marketable or usuable elsewhere.

\subsection{The Basic Assumption}

There are five basic assumptions in the pursuit and analysis of South-South relations. The first is that Third World countries together form a mass of the victims and the powerless in the international economy 17 and that this forms the basis for cooperation in fighting against this situation. The second presumption is that countries of the South have a common interest due to common basic economic features. 18 The third presumption is that this common interest has led to attempts to cooperate and attain collective self-reliance, but the biggest problem has been poor organizational infrastructure. 19 The fourth assumption is that there is a common understanding about the objectives of collective self-reliance and it is attainable. 20 The fifth assumption is that South-South trade is free of super power politics 21 and perhaps free of exploitation.

15 A. M. Mazrui, Afro-Arab Relations and the Role of the Gulf States of Eastem Arabia, India Quarterly, Vol. 31 (1975), No. 3., pp. 304 - 307; W. R. Johnson, Africans' and Arabs' Collaboration without Cooperation without Challenge, International Joumal, Vol. 35 (1980), No. 4, pp. 766 793; R. Acciaris, Cuba's Economic Relations with Latin America and the Caribbean, Soviet and East European Trade, Vol. 20 (1984), No. 3, pp. 3 - 79.

16 See Johnson, above, fn. 15; C. P. Hallwood / S. W. Sinclair, The Non-oil Developing Countries and OPEC: Coalition or Conflict?, Intereconomics, Vol. 19 (1984), No. 6, pp. 260 - 297; G. Shreeve, Political Tensions Cloud Arab-African Cooperation, Middle East Economic Digest, 1984.

17 See J. K. Nyerere, South-South Option, in: A. Gauhar (ed.), Third World Strategy, New York, 1983,p. 10.

18 Carlsson, above, fn. 7, p. 29.

19 K.P. Sauvant, Organisational Inf rastructure for Self-Reliance: The Non-Aligned Countries and the Group of 77, Development and Peace, Vol. 3 (1982), No. 1, pp. 12 - 39; S. S. Ramphal, Shridath Ramphal - Interview in Talking About Development, in: A. Gauhar (ed.), Third World Foundation, London 1983, pp. 23 - 68.

$20 K$. Hope, Self-Reliance and Participation of the Poor in the Development Process in the Third World, FUTURES 15/1983 (6), pp. 455 - 462; K. P. Sauvant, From Economic to Socio-Cultural Emancipation: The Historical Context of the NIEO and the New International Socio-Cultural Order, Third World Quarterly, Vol. 3 (1981), No. 1, p. 48; B. Hashemi, Collective Self-Reliance Through Joint Industrial Projects: Case for the Arab Countries, New York 1981, UN (DTCD). 
Other presumptions can be drawn from the theories of intemational trade. The neo-classical theory holds that intemational trade becomes more rewarding, when it takes place between parties with dissimilar levels of economic development, e.g. North and South assuming that conditions for producing technology are similar in most situations. 22 This theory known as the Hekscher-Ohlin theory has been used to explain the increasing benefits of trade among unequal partners in the North-South trade but does not explain whether trade among countries with unequal factor endowment benefits both parties equally. Another theory by Burenstam-Linder is that the greatest gains occur between countries with the same level of development, i.e. similar income levels, market structures, technological levels ets. and that gains are lesser between unequal partners. While the Hekscher-Ohlin theory fails to explain why trade between industrialized countries of the North remains very lucrative and dynamic, the Burenstam-Linder thesis fails to explain why trade among the poor countries of the South sharing common features is less dynamic and less lucrative than North-North trade. 23

Attempts to answer this question have been made by several researchers. Frances Stewart 24 has argued that the economies of the South have been channelled by their colonial past and their present integration into the economies of the North to have trade flows which become dynamic only for the North. Vemon 25 has also argued that there is a product cycle syndrome under which trade flows will be North-South for technologically new products and South-North for mature products. Carlsson explains this further by arguing that, as long as the new technologies are produced in the North, North-South flows will continue to be stronger. 26

Other possible explanations are, first, that the assumption that countries of the South are necessarily at the same level of development is false and that, therefore, they have different goals in the way they approach their own cooperation. The second is that the South-South strategy has taken off from the wrong point with most participants looking at is as a catchup exercise and trying to use it to get out of the South. This may be making South-South relations equally or even more exploitative than North-South relations and, subsequently, less attractive for disadvantaged partners. In the same vein, it is possible that the SouthSouth exchange is based on the exchange of pressures arising from the North-South relations. Almost invariably all countries of the South are heavily indebted to the North. Most

21 Sauvant, above, fn. 20; S. S. Ramphal, South-South: Parameters and Pre-Conditions, in: A. Gauhar (ed.), Third World Strategy, New York 1978, pp. 17 - 23.

22 Carlsson, above, fn. 7, 1982

23 Carlsson, above, fn.7, 1982.

24 Frances Stewart, The Direction of Intemational Trade: Gains and Losses for the Third World, in: G. K. Helleiner, A World Divided, Cambridge 1978, p. 94.

25 Vernon 1966

26 Carlsson, above, fn. 7, 1982. 
of them are wriggling under a sqeeze on the intemational finance and other markets. All of them have no option but to turn to the South. They may, therefore, be looking at SouthSouth trade as a fire exit and as a possible source of better benefits which can be used to make peace with the North. This may partially explain why in some cases South-South trade has been more unconscionable and more devastating for the weaker partners such as Tanzania. In the next sections, evidence is given of some aspects of this assertion.

\section{South-South Trade and Technology Transactions Involving Tanzania: 1970 - 1980}

In this section, three types of transactions between Tanzania and some Third World countries will be examined. First, we shall examine technical assistance and licensing agreements. Then, we shall examine procurement or machinery supply agreements between selected supplies and selected recipients. Finally, we shall have a look at construction and engineering transactions. All these transactions involve supplies from four prominent members of the Non-Aligned Movement - China, India, Jamaica and Yugoslavia. Most significant, however, is the fact, that, at the time the transactions took place, the leaders of these countries, i.s. Mao, Gandhi, Manley and Tito, together with Julius Nyerere of Tanzania, were at the front line of the search for an equitable and new intemational order. Equally significant was the fact that the agencies involved in some cases were public enterprises.

\subsection{Technology and Technical Assistance Agreements}

The phrase "technology agreements" is used very liberally to refer to licensing agreements and other transactions involving the purchase of know-how embodied in human skills and excludes any hardware form of technology. Between 1970 and 1980, Tanzania embarked upon a very clear policy of relying on technical skills available in developing countries before tuming to developed countries. Among other numerous transactions with Third World suppliers of know-how and technical skills including Brazil, Pakistan, Iraq, Egypt and Mexico, it entered into technology agreements with two Indian companies.

The first of them was with National Industrial Development Corporation for technical assistance in food production and the second one was Kamataka Implements and Machinery Co. Ltd. of Banglore which, with the assistance of Munkand Iron and Steel Works of Bombay, undertook to supply technical know-how for the construction of a steel rolling mill. These undertakings were in 1973. During the same year, the National Textile Corporation in Tanzania entered into an agreement with an American firm known as Cluett, Peabody Sanforzed Co. of New York for the supply of machinery and anti-shrinkage technology to its subsidiary company at Mwanza, Tanzania. In 1974, the State Mining Cor- 
poration entered into an agreement with a Yugoslavian firm, ENERGOPROJECT, for technical assistance in the design and construction of a cement factory at Tanga. In 1976, the Tanzania Sisal Corporation entered into an agreement with Jamaican Organic Chemicals of Kingston, Jamaica for the establishment of a sisal juice extraction plant, and the two formed a joint venture company known as SISALANA (T), Ltd.

Therefore, the companies which are the subject of discussion were drawn from a wide spectrum of countries - a self-managed socialist firm from a founder member of the NonAligned Movement, a firm from Jamaica, one of the radical founders of the Group of 77 , and a traditional supplier from the North and specifically the U.S., one of the targets of the demand for a new international economic order. What is striking about the behaviour of these actors is that irrespective of their origin or the predominant ideologies in their countries, all without exception, used a standard from of technology contract. Secondly, all the agreements reflected the traditional inequities found in the North-South technology transactions. This phenomenon was due to, among others, ten factors.

The first factor was that of duration. It has been noted in other countries that traditional suppliers of technology tend to try to maintain patent agreements for longer periods of time even where patents are no longer valid in countries of origin.27 In all the contracts involving countries listed above, there was no clause specifying the duration of the agreement. In the case of food technology from the NIDC of India, there was, as we shall see, no specification of the know-how to be transferred. The same went for JOC from Jamaica. The refusal to be specific about duration was calculated in most cases to make technical assistance, the main source of fees over a long period of time irrespective of whether such assistance was rendered or not.

This brings us to the second factor. Although, in the agreements with these five companies, it was agreed that skills would be exercised by the foreign companies to help host companies, the skills were not specified anywhere, This was more pronounced in the NAFCONIDC agreement and the CLUETT-TEXCO agreement for transfer of anti-shrinkage technology. In the former the Indian firm gave a warranty that it had world wide experience in food production technology. The specific nature of the skills and experience that would be deployed in Tanzania was not agreed upon. In the case of latter, there was also a warranty of proficiency and world monopoly of anti-shrinkage techniques. But it was agreed they would be supplied at the choice and discretion of the suppliers.

The third factor is that know-how and assistance in the five agreements expressly covered very elementary processes which could be performed by local experts. Most of these

27 M. Odle, Technology Leasing - Guyana and Trinidad, Social and Economic Studies, Vol. 28 (1979), p. 190. 
covered feasibility studies, preliminary design and pre-investments analyses. None of the suppliers committed themselves to undertake serious engineering work or to train local people to manage and run intended projects or processes. Outstanding examples here were KIMCO of Bangalore together with Munkand of Bombay in the steel rolling mill project on the one hand and Energoproject of Yugoslavia in the cement project.

In the steel rolling mill project, both the Indian firms gave detailed warranties of knowledge and experience in steel mill design and engineering. None, however, undertook to sell the local company any soft-ware components of technical know-how such as manuals, blue prints, patents etc. All limited themselves not only to design work and supervision of tenders, but undertook to identify suppliers of machinery without being responsible for its supply or installation. Similarly, the Yugoslavian firm confined itself to the supply of professional services such as preparation of documents, pre-design tests, organization of tenders and supervision of construction. As will be seen later, they were charging very high fees for this role. In both cases, the foreign companies were avoiding the supply of technology embodied in any other components than human beings so as to minimize grounds for evaluation of their competence, negligence or non-performance.

The fourth factor was that in each of the cases foreign companies promised to supply patents and other related forms of technology. But there was no list of these patens for the verification of their existence. There was no schedule in any of the agreements pointing out the characteristics or mode of applications of these patents or in some cases trade marks. Furthermore, the management agreements accompanying these arrangements did not make any distinction between management as a technical skill and technical know-how embodied in other sources of technology apart from human skills. There were no in-built enforcement mechanisms through which technical know-how could be transferred.

The fifth factor is that in the case of Jamaican, American and Indian companies, the patents which, though not specified, the agreements aimed at, covered processes which were very old. Hence, most of them had been exhausted in their countries of origin or intermediate countries of use. Hence, the same tradition of shifting production centres from the centre or semi-periphery to the periphery 28 was being repeated or a pretence being made to that effect. Both in the case of the Jamaican company, JOC, and the American company Cluett, the transfer involved machinery no longer in popular use in the exporting countries. The difference was that the American company supplied new machinery with obsolete technology and the Jamaican company supplied machinery already used in the extraction of sugar and cane juice for the extraction of sisal juice on trial basis. 
The sixth characteristic factor is that the performance of these agreements was contingent. Most clauses tied disclosure of technical information to the possible future changes in needs or other circumstances. Cluett undertook to send technical advisors only if such a visit coincided with a general African tour by such experts. How often these general tours were going to be made was never disclosed. In the case of food technology, NIDC of India only committed themselves to supply such information as would arise in future.

The seventh factor was that in the majority of the five cases, management consultancy agreements involved an abdication of powers by local firms. In the case of JOC, it undertook to manage and control the entire decision-making process, In the case of NIDC, it was given more powers than were necessary for its technical assistance, e.g. recruitment of all local and foreign personnel, acting as agents for the purchase and sale of inputs and products respectively, etc. In all cases, the "exclusive management" clauses gave foreign firms political leverage which they used to increase their influence on the economy and maximize their economic gains. All these were restrictive practices which reflect unequal relations between recipients and suppliers of technology. They are used by traditional technology suppliers to maintain control of their know-how 29 and also to block any possible unintended transfer of technology. 30

This was further supplemented by restrictions on the right of the recipient firms to modify any patents and retain control over the improvements. Although no specific patents were released at the time of agreement, most of the contracts protected the rights of the foreign companies over improvements on their know-how, even if such improvements were effected by the recipient firms. In the case of Energoproject, the protection was extended to any information, data sheets, etc. that would arise from the testing and designing processes. Such clauses are typical in standard contracts with MNCs and are aimed at minimizing the learning or transfer effect of knowledge in order to ensure the supplier's technological superiority. In extreme cases such restrictions were extended to debris or garbage arising from technical processes.

The ninth characteristic of the five agreements was that they covered too wide a ground. Most clauses were anticipatory and covered envisaged and envisageable processes. Hence, they covered pre-feasibility and feasibility studies, tests and designs, the preparation of tender documents, tenders and the supervision of tenders, the choice of suppliers, the recruitment of personnel, training, accounting, marketing and many unrelated future activities, etc. They also undertook to advise on research and development. Most of these provisions, if implemented, would have had the effect of keeping out other possible actors, i.e.

29 S. Cardinale, Doing Business Abroad, A Practising Law Institute, Vol. 2 (1964), p. 586.

30 Odle, above, fn. 28, p. 190. 
limiting the choice of the recipients and, also, clocking the diffusion and assimilation of the know-how contracted about.

Finally, there is the issue of cost. Cluett supplied machinery which could be easily obtained on the market but leased it at an annual rent of $\$ 10,000$ per machine per year. JOC offered to buy the sisal juice extracted under its supervision at $\$ 50$ per 10,000 litres. Energoproject demanded and obtained as much as $\$ 875,000$ for design work only excluding the costs for administering tenders, geological surveys, geo-chemical tests, daily transport, research expenses, living expenses, etc. In addition, specialist engineers were paid US\$ 6,600, senior engineers US\$ 4,800, engineers US\$ 4,200 and technicians US\$ 4,000 per month for eight months. Equally exorbitant sums were paid to the Indian firms and their experts. As will be argued later, for the recipient firms it did not so much matter who the suppliers were. The terms offered by companies were in no way different from those offered by Cluett from the North. The same was experienced in the case of machinery supply. Using the same companies, let us see the specific characteristics of some of these supply arrangements.

\subsection{Trade Machinery and Equipment}

In the area of machinery and equipment, South-South transactions have been more problematic than in other areas. The main constraint has been poor quality arising from the nature of the production techniques and quality control capabilities in the Southern suppliers states. In many Southern industrializing states, the technologies used are not the newest or most efficient and the quality is kept low by the ever-reliance on cheap labour. Although these shortcomings are obvious, one would still expect a modest supplier trying to supply the best under the best terms given the spirit of South-South cooperation. This has not been the case.

The terms have not been better than those from the traditional suppliers. For example, there has been a conspicuous lack of performance guarantees. Most supply agreements contain warranties about the proficiency of the supplier but not about the efficiency of the supplies equipment, hence no performance guarantee period. The second example is that most contracts contain an "owner's risk clause". Some of such clauses even cover the period of assembly or manufacture when the products are still in the yard and under the control of the supplier. Another feature is that where the goods are being "manufactured" or assembled, most agreements do not give the buyer the right to inspect. Some of these problems arise from lack of resources on the part of the buyers and some from excess of trust in suppliers. However, there is evidence in most cases of a blatant violation of trust. One transaction will be used to explain this. 
In 1976, the government of Tanzania approached the government of India for technical advice on how the former could overcome her shortage of railway waggons and engines caused by the disruption of the East African common services, when the East African Community broke down in 1975. The government of India sent a team of experts who, after studying Tanzania's railway system, recommended that Tanzania acquire fifteen new diesel locomotives and five second-hand steam engines from India. At the time the report was presented it was intimated that India would not only be able to supply the machines but also a soft loan to cover the transactions. Encouraged by the report, the Tanzanian government took the offer of support seriously and started the negotiations.

The initial negotiations were of a bilateral nature but contrary to Tanzania's expectations, almost immediately the Indian government delegated the negotiations to a public enterprise called Indian Properties and Projects, Ltd. In response to this, the Tanzanian government stepped out of negotiations and left them to the Tanzania Railway Corporation. In the second phase of negotiations the Indian party disclosed that they had no knowledge about the possibility of a soft loan and that they would not release any consignment without initial payment. At the same time, the Tanzania Railway Corporation got involved in the negotiations with a Belgian Company chosen by its government for the supply of a dry-dock. Incidentally, the negotiations and consequent terms in the two deals came out with similar features.

The first feature was that in both cases the supplier companies insisted on drafting the agreements and retained all the terms they wanted. Hence, the negotiations were made subject to what the supplier permitted to be negotiated. The second feature in both was that there were no supplier warranties especially warranties of skills and performance. The third feature was that in both cases the operation of the agreement was made subject to the occurance of a future supplier-controlled event. For example, the coming into operation of the locomotive agreement was made subject to the locomotives being able to run on Tanzania's rail at the speed of 80 k.p.h. and the dock agreement was made contingent upon the Belgian government accepting to finance a separate project for the assembly of the dock in Mwanza.

The fourth feature was that in both cases the agreement contained technical specifications. But those specifications were made by the suppliers and inspite of attempts the recipients were refused permission to change them. In spite of this, the supplier retained the right to alter them unilaterally at any time before the supply of the manufactured goods. The fifth was that in neither of the agreements technological and technical guarantees had been made. The only guarantee made was that the goods would be free from defect. What was needed was the guarantee of efficiency and suitability for the purpose for which they were being acquired. Sixth, in both agreements, the buyer was given no right to control the manufacturing process by way of inspection of materials or the construction processes. In 
addition the manufacturers got the right to subcontract their responsibility to subcontractors of their own choice. In all these, the opportunities of the recipient to acquire technological capability either through observation, exposure or through leaming by doing were completely blocked.

Similarly, both agreements contained unfair provisions on the transfer of property and the risk in the property. In both cases the property and the risk passed to the buyer as soon as they left the premises of the seller. The locomotives were both free on rail (FOR) and free on board (FOB). In ordinary FOB transactions, the risk attaches only after the goods have been entrusted with a shipper and after the buyer receives shipping documents. In the case of the locomotives from India, the contract went further to say the risk would attach as soon as the goods were put alongside a vessel. Furthermore, both agreements had no provisions goveming breach of contract. Each of the sellers drafted the agreement in such a way that it left the loss to lie on the buyer in case of breach.

These agreements were very important in covering the sellers in the subsequent breaches of traditional terms of contract. When the goods were supplied it was clear that express and implied terms of agreement had been violated. In both cases for example, there was a condition that goods stated to be new would be new. It transpired in the Indian locomotives deal that the diesel locomotives were not new at all. This was betrayed by the following. First, the first consignment came within a very short time, although it was envisaged that they would be manufactured. Second, after the locomotives were offloaded, two of them failed to start while in the harbour and never managed to take off at all. Third, out of the remaining thirteen engines none of them could manage to pass the initial test at low gradients. Fourth all of them started smoking and showing signs of overheating during the initial tests and smoking got worse at very low gradients. Fifth, during the initial tests, the horse-power output of all was below the level specified, and this remained the case after they were derated. Sixth and very fundamental, the engines of five of them cracked within three months and when they were opened for repairs, some cylinder heads were found to be bigger than the valves and cylinders and some pistons had sharp edges which showed signs that there had been resurfacing of some engine parts during the "manufacture". Some piston heads had dents which would not be expected in any new engines. Other defects which began showing too early included light failure, poor scavenging, oil leakage and fuel injection nozzle failures.

Similarly, the dry-dock from Belgium was far from new. It had been used elsewhere and was very hastily assembled. When it was re-assembled in Mwanza, it turned out to be much smaller than had been anticipated and could not even handel the biggest existing ship, the MV Victoria. If the MV Victoria were to use its facilities it would have to have half of its mast cut off. Hence, it has not managed to solve the problem of Tanzania's dependence on the dock in Kisumu, Kenya, as had been anticipated. Both deals involving the Tanzania 
Railway Corporation, two different types of equipment and one supplier from the North and one from the South, seem to have produced equal results for Tanzania. Finally, another deal involving construction shall be examined in order to see, whether these results have to be considered exceptional.

\subsection{Engineering and Construction Contracts}

The story of leaking silos constructed with the aid of the Swedish International Development Agency in the late sixties has been well documented by Coulson. ${ }^{31}$ In the late seventies, the role of Ballast Overseas Construction Company and some Israeli construction firms in putting up buildings which later collapsed became a sensational issue. 32 After 1975 , such contracts and construction deals became common. They included plants which were paid for but not set up at all or which were abandoned at foundation stage such as the meat canning plant at Shinyanga and the brick factory at Arusha which was supposed to be run by an Indian firm. Instead of running it, the of ficials of that firm brought the equipment, established a construction site and ran away. The most recent construction set-back was the Mbeya Textile Mill which was so poorly constructed that, when the plant started operating, the floor cracked diagonally. After a few months the building started trembling and quaking whenever the machines were switched on. Most of these plants have been built by companies from the North.

The Southern companies have also had their pound of flesh. In a totally different way, China as a big brother in the South, has had its share of the blame. In 1970, an agreement was finalised for the construction of the Tanzania-Zambia Railway. In 1975, China had finished the railway and was able to hand it over. This great railway was not only proof of socialist efficiency but of how a poor Third World country can succeed where the giants had feared to attempt. However, inspite of the great contribution made, three thins made the deal unreasonable for Tanzania and Zambia. First, the deal was that China would manufacture all components in China and transport them to the site by ship and later road or rail. Hence, payment was made to cover the CIF of all components. What was never discovered until ten years later, i.e. five years later after the handover, was that no single component was manufactured in China.

During the construction, the Chinese built an underground steel plant in the middle of a thick forest in Mang'ula area, Morogoro Region in Tanzania. Using the ore that they got by breaking through the Chunya mountains and the immense coal deposits in the same belt, they managed to smelt iron and steel and prefabricate rolling stocks and the railway line

31 A. Coulson (ed.), African Socialism in Practice: The Tanzanian Experience, Nottingham 1979.

32 I. G. Shivji, Blood-Sucking Contracts, University of Dar es Salaam 1973. 
from there. In most cases the transportation of the prefabricated lines and their laying was done at night. The government of Tanzania never knew until 1981 that a fully-fledged underground steel plant with prefabricating capacity existed. It was voluntarily handed over by the Chinese, then their contract expired.

The second aspect is that, although the agreement anticipated that the Chinese workers who worked on the railway line would be wage workers, it seems the Chinese construction relied mainly on prison labour. Given the fact that the three partners were all socialists, this may not have been the best labour for a "liberation railway" or "uhuru railway" as it is now known. But still important is the fact that there were no wages involved. The sacrifice involved was so much that more Chinese died in the five years of construction than Indians who had been in East Africa before the British colonialists.

The third factor is the speculation that a lot of minerals were transferred throughout the construction process. This allegation has never been substantiated, but has been confirmed by Tanzanian workers, who worked with the Chinese in the construction process. Due to trust, most Chinese were not being subjected to customs checks on their exit back to China. Almost invariably, every Chinese was going back with a very big wooden crate and they were going back in huge numbers from time to time by ship. It is speculated that there were ores and precious metals in those crates. But it is important to stress that this claim has never been substantiated. Finally, it is also important to acknowledge that China has been a very reliable trade partner with many developing countries between 1955 and 1985, a time during which these countries needed a lot of support. 33

\section{Conclusion}

One major criticism of this paper will be that issues of the South better be discussed in the South and that to attack South-South relations whilst based in the North renders itself very suspicious. Two explanations may be offered which may not necessarily be satisfactory. First, it is not easy to find South-South non-protocol groups or circles in the South. The South-South groups with the time to ponder and exchange views are in the North, especially academicians etc. Secondly, it does not help the South to take a mute and muffled approach in issues of policy and strategy. Reluctance to be self-critical in the confused belief that self-examination connotes lack of militancy is a real problem for progress in the South. As Ramphal has said such defensive attitudes are a legacy of the colonial struggle and the overwhelming need for solidarity. 34 Furthermore, there is too much nationalism in

33 S. Paine, China's Economic Relations with Less Developed Countries, in: D. Nayyar (ed.), Economic Relations Between Socialist Countries and the Third World, London 1977.

34 Ramphal, above, fn. 1. 
the South and, when generalised at level of the countries in the South, this nationalism supresses all the necessary processes of inquiry, evaluation and innovation. It is this nationalism that has made flag independence meaningless in the Southern states and, when generalised, it threatens to make South-South cooperation purely rhetorical and enigmatic.

The experiences seen in the preceding pages tend to show a few things. First, they show that trade is not a psychological phenomenon, but a socio-economic process of exchange of values. It has been in existence for a long time, has developed rules, norms, values and pattems which cannot alter themselves simply because they are frowned upon by some people. They have to be consciously changed and replaced by new desired ones. Customs and practices die hard. Who would think that the Chinese merchant under Mao's socialist system would retain the characteristics of the Chinese merchant of the oriental mode as seen by Marco Polo - with two separate scales and using one when buying and another when selling? In any case, there is no reason to expect that the Chinese in Deng's China would change automatically. The South-South cooperation may be more likely to attain if, as Nyerere has argued, it is based on a new outlook of relations between the developing countries and a new framework of relations. 35

Secondly, it is crystal clear that using the existing trade framework, every country is trying to use trade to solve its own global problems, most of which have their origins in the NorthSouth relations. This in itself destroys the philosophical basis of South-South trade, because in any case the North is still involved. But more fundamental is the problem of attacking North-South relations without condemning and abandoning their patterns. This makes it seem as if the South is condemning the North because it covets it and not because it disagrees with ways in which cooperation is organised in the North itself or between it and the South. .

Third, it is noteworthy that exploitation is still regarded as sweet by some Southern firms or countries and it is only bad when it is against them. It seems that, given a chance, some countries now exploited would not mind exploiting some of their present exploiters or some of their fellow victims. This outlook, philosophically strengthens the case for North-South inequities in trade and investment and with it, we may as well abandon the South-South discussions. Nyerere has wamed that,

if within the Third World those with advantages seek to exploit the weaker ones, then we shall simply repeat, amongst ourselves at a lower level, the kind of dependency imbalance which now exists between the South and the North.36

36 Nyerere, ibd., p. 15. 
As mentioned earlier, if by South-South rhetoric we are generating an ideology which can be used to create a fourth world in the absence of a world war, then we are in the process of building up mutual resentment, competition with and domination of one another. We may be already creating the North of the South and, for some countries, once you cross the national borders you may already be in the North.

There is a need to do several things. First to intensify dialogue and debate amongst ourselves and to identify what we want and how we would like to relate to each other. We may have to find out ways of departing from traditional patterns of cooperation without causing much disequilibria in our economies. We have to develop our own instruments of trade cooperation and our own codes of conduct. Second, we have to strengthen regional integration as the only basis for meaningful development and coordination of joint interests and policies. We cannot expect to cooperate at arms length and, if we have no tradition for charity at home, we should not expect it away from home.

Third, we should get out of the practice of making it seem that we hate the existing order, because we are at the wrong side of it. We must develop a philosophical hostility to exploitative relations of all kinds by whomsoever perpetrated. Only if we are firmly committed to democratic and exploitation-free economic relations, we can make an effort to develop institutions for attaining such relations and use these institutions to show others that such relations are possible. Otherwise, the North-South dialogue for a new economic order remains a self-serving rhetoric and South-South cooperation a high-sounding but fundamentally empty diplomatic puff. 
and procedure, evidence and civil (other than matters of family and succession) law. Here, Islamization of the laws raises the fundamental problems of democracy, secularism and human rights of all persons. Additionally, for non-Muslim Sudanese, Islamization of the laws and constitution imposes on them disabilities somewhat analogous to those attaching to foreigners in a secular state.

Practical Problems in the South-South Development Cooperation: Some Experiences Involving Tanzania

\author{
By Paschal B. Mihyo
}

South-South economic cooperation for economic change has a long tradition. Starting with a historic glance at the first Afro-Asian Conference at Bandung in 1955 and the development to the present situation, the article focusses on the role of the non-aligned movement in the development of the South-South development cooperation. After considering the specific issues and difficulties of South-South cooperation, its basic forms and assumptions are examined. Evidence of the assumptions is given by an evaluation of the characteristics and weaknesses of selected specific cooperation projects between Southern states and Tanzania between 1970 and 1980 in the areas of, first, technology and technical assistance agreements, second, in the area of trade of machinery and equipment and, finally, engineering and construction contracts.

The author comes to the conclusion that, since the difficulties are, to a considerable degree, based on the values of the partners involved, they can only be changed consciously and slowly. He contends that the South-South cooperation may be more likely to succeed if, as Nyerere has argued, it is based on a new outlook of relations between the developing countries and on a new framework of relations. Mihyo concludes, firstly, that the dialogue and debate amongst the Southern countries has to be intensified and their goals have to be clearly identified. New instruments of trade cooperation and own codes of conduct have to be developed. Secondly, regional cooperation has to be strengthened as the only basis for meaningful development. Thirdly, only a firm commitment to democratic and exploitationfree economic relations between countries of the South can form a solid basis for the development of new institutions of economic cooperation. 